\title{
1980 年代の海底地震観測
}

\author{
東京大学海洋研究所* 末 広 潔 \\ Seafloor Seismic Observations in the 80's \\ -A review-
}

\begin{abstract}
Kiyoshi Suyehiro
Ocean Research Institute, the University of Tokyo, 1-15-1, Minamidai, Nakano-ku, Tokyo, 164 Japan

(Received December 8, 1990; Accepted November 14, 1991)
\end{abstract}

\begin{abstract}
A review of seafloor observations of seismic waves is presented, highlighting progress in the 80's. Observations made by ocean bottom seismographs have proved superiority in the acquisition of better quality data than conventional surface hydrophone observations and in determining more accurate seismicity and seismic structure in ocean areas. The decade has seen developments of highly reliable instruments which can be deployed in tens of quantity. Efforts are continuing to broaden the observational window in the frequency range and dynamic range, which require to overcome noise problems linked to observational site and instrument coupling parameters. Long-term observation is also another important goal for the next generation of seafloor seismic instruments to construct a truly global seismic network.
\end{abstract}

Key words: OBS, Seafloor observation, Seismic instrument.

\section{§1.はじめに}

地震観測によって得られるデータから地球内部の構造 と地震波の発生機構（ふつうは地震）が調べられる。 そ の有用性は, 他の地球科学分野あるいは工学ともリンク して学際的である.したがって地震観測には多岐の目的 がありうる，それによって，対象となる地震（巨大地震 から微動まで), 地域（地球全体から「庭」の広さまで） が変わるが，海底地震観測はそのほとんどすべての目 的，対象についての新しいデー夕を提供するすのとして 期待されてきた．地震がそもそも海底下に多く発生する こと, 内部構造が海と陸と異なることが理由である.

地動を正確に捉えようとする点ではどこで地震観測し ようがかわりがない。しかし海底地震観測は，ほかの海 域での地球内部観測と比較しても同様あるいはそれ以上 に技術的困難が伴う。そのためこれを克服する努力に大 きく重点が置かれてきた，短い時間で見るとコストイ フェクティブではない研究と映るが，これまでをずっと 振り返ると大きな学問的貢献を生む方向をめざしてかな りの道のりをあと一歩まで来たようにみえる，ほんとう

* \%164 東京都中野区南台 1-15-1
にそうか, ここに 80 年代の海底地震観測の状況を中心 にレビューを試みる.

そもそもの歷史は戦前（1937 年）まで遡る [例えば EwING and EwING (1961)]. Ewing, Sutton らを擁する ラモント地質学研究所は 1960 年代まで海底での爆破, 音響デー夕伝送, ケーブル式, 長周期観測をシステムに 含む先駆的な挑戦を続けた [EwING and EWING (1961), SutTon et al. (1965)]. その後日本を含めた各国で海底 地震観測の試みが進められ 1960 年代後半 [例えば, 浅 田・島村 (1974), NAGUMo and KASAHARA (1976)], 1970 年代 [島村 $(1981,1988)$, 島村 - 浅田 (1978)], そ して 1980 年代と観測方式を進化させるとともにデー夕 あ蓄積されてきた，論文あ増加の一途である．全体を俯 瞰できるように海底地震観測史上重要と思われるできご とを表 1 にあげておく．略号については補遺に対照表を 掲げた。

そのような海底地震観測む後で述べるようにここに転 機を迎えた兆しがある. 一つには, 海底地震観測の先進 国日本では誰でも海底地震観測ができる時代になった。 海底地震観測の経験をもつ国内の研究機関は少なくとも 10 ある.それだけノウハウが蓄積しシェアされるよう 


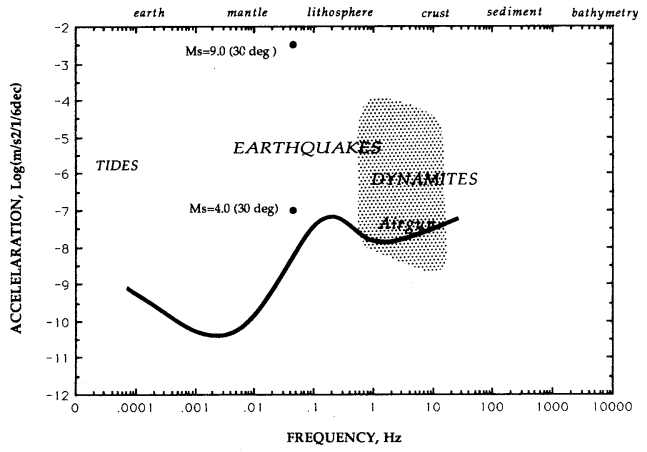

Fig. 1. Seismic observational window as seen in frquency-amplitude domain. Stippled area is typical observational window of existing OBSs. A low noise model curve is indicated.

になった背景にはたいへんな努力があった，現在であ観 測点へのアクセス，つまり適切な船を確保することが簡 単ではないことがネックになるが，10 年の基礎実験を 要するという時代は去ったかにみえる. 一方, 現在のか たちの海底地震観測のままでよいと考える人は少ない．

観測の「空」をさらに広げたあらたな実験がプレートテ クトニクス説以後の新しい展開を生みだすことが期待さ れるからである (Fig. 1).
この報告は海底地震観測法の決定版を提示することが 目的ではないしそもそも決定版があるわけであない，詳 しい具体的な技術のまとめは例えば友田・他 (1985) の 第 9 章 4 節, 気象研究所地震火山研究部 (1980), PROTHERo (1984), WHITMARSH and LILWALL (1983), ある いは参考文献としてあげた個々の原著論文を参照してい ただきたい，ここでは網羅を心掛けるよりまずバラエ ティーに富むと言われる OBS (海底地震計) とはどうい うあのか，つぎに 80 年代を画すると思われるいくつか の実例を通して海底地震観測とは何を狙い, どのように 行われるのか示し，さらにカップリングとノイズのよう ないくつかの問題に注目した後, 90 年代に予想される 展開を述べる.

\section{§2. OBS とはなにか}

\subsection{OBS}

OBS は海底のゆれを忠実に記録しわれわれの手に届 けなくてはならない。この実現のために, 地震波を感知 するセンサー，その出力を記録しやすい信号に変換する エレクトロニクス部, 時刻を含めた記録系, 電源部, 回 収装置を組み合わせる，その機能は，どこでどのくらい 観測したいか, 自然地震か人工地震か, 何台のネット ワークにするかなどの目的により制約条件が変わり設計 


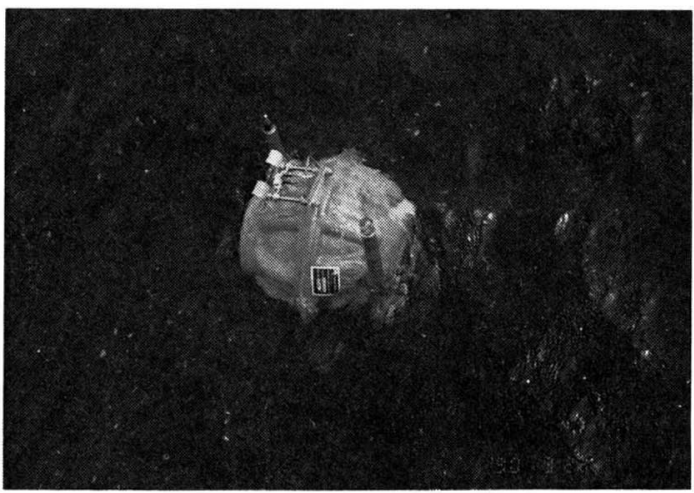

(a)

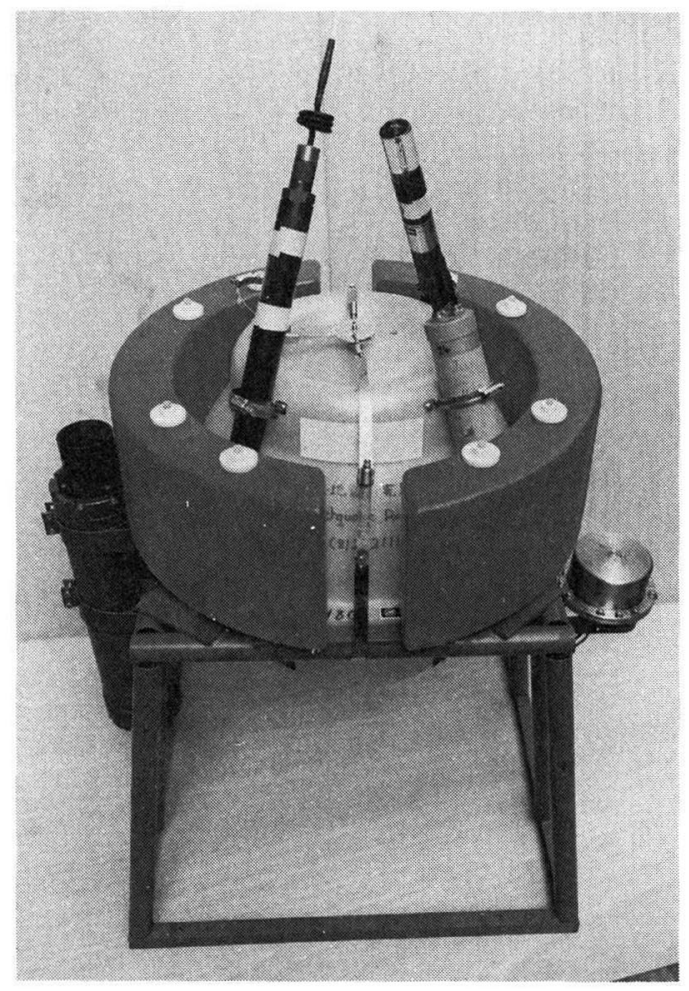

(b)

者の思想が加わってバラエティーができる，ここでは日 本の代表的な OBS の例を Fig. 2, 表 2 に示す.

OBS の利点は海面で観測するッノブイ（ハイドロホ ンをつり下げたブイから信号を電波で飛ばす）よりノィ ズが低い, 漂流しない, 測定対象に近い, S 波も観測で きる, が挙げられる、この利点を生かせるようになった 現在, 日本では OBS 観測は陸上の臨時観測に出動する と同様のレベルに達した部分がある. ほとんど $100 \%$ の データ回収率でもって短時間に実行でき，したがって多
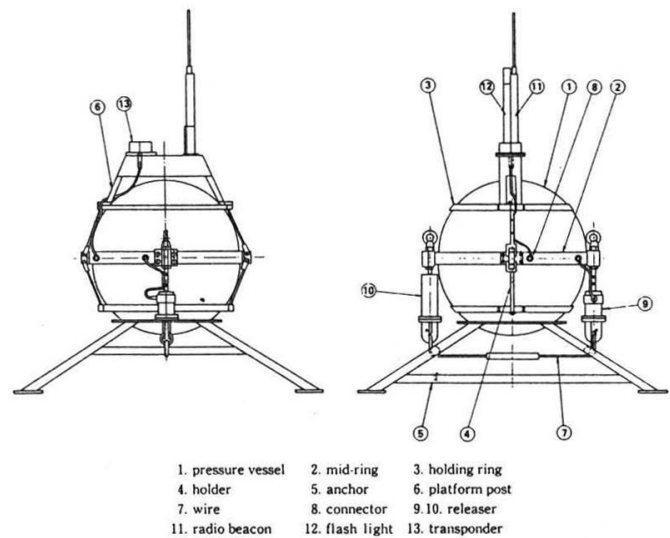

(c)

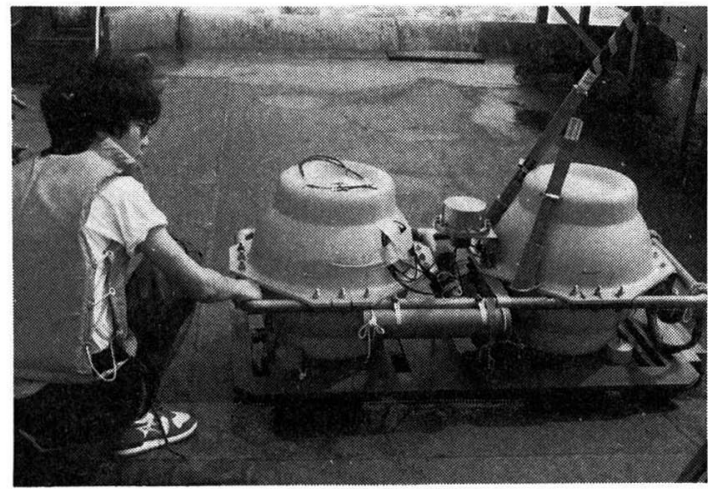

(d)

Fig. 2. Examples of pop-up-type OBS systems developed in Japan. (a), developed at Laboratory for Ocean Bottom Seismology, Hokkaido University and Geophysical Institute, University of Tokyo [金沢 (1986)]; (b), developed at Earthquake Research Institute [笠原・他 (1979), 南雲・他 (1982)]; (c), developed at National Research Center for Disaster Prevention [Fujinawa et al. (1987)]. (d), developed at Chiba University. See Table 2 for specifications.

点観測ができる. 地震予知計画， あるいは DELP 計画 (1984〜89) ではこのような手法の観測が機会があれば ほぼいつでもできる態勢にある. 測器, 観測とも経験と 共に改良を重ねているが, ルーチン化されたとみること あできる.つまりこの種の OBS に合目的的な観測はサ イエンスの結果が問われるようになった.

\section{2 設置と回収}

設置と回収は, 以前は海面のブイとロープで結んだア ンカードブイ方式がさかんであったが現在ではその簡便 
表 2 海底地震計の例

\begin{tabular}{|c|c|c|}
\hline & ERI-AR81 & CDPOBS IIa \\
\hline センサー & $\begin{array}{l}\text { 上下動: マークプロダクッ L-22E }(2 \mathrm{~Hz}) 1 \text { 成分 } \\
\text { 水平動: マークプロダクッ L-22E }(2 \mathrm{~Hz}) 1 \text { 成分 } \\
\text { ハイドロホン: OASE-2SD }(\mathrm{DC}-5 \mathrm{kHz})\end{array}$ & $\begin{array}{l}(4.5 \mathrm{~Hz}) 1 \text { 成分 } \\
(4.5 \mathrm{~Hz}) 2 \text { 成分 } \\
\text { なし }\end{array}$ \\
\hline 方位計 & なし & あり（精度 5 度以内） \\
\hline 記 録 器 & $\begin{array}{l}\text { カセットテープ直接アナログ記録 } \\
\text { 速度: } 0.132 \mathrm{~mm} / \mathrm{s}(15 \text { days } 120 \mathrm{~min} \text { tape }) \\
\text { 周波数: } 1-30 \mathrm{~Hz}(-6 \mathrm{~dB})\end{array}$ & $\begin{array}{l}\text { オープンリール } 14 \text { チャネルアナログ } \\
0.15 \mathrm{~mm} / \mathrm{s}(42 \text { days }) \\
1-30 \mathrm{~Hz}( \pm 1.5 \mathrm{~dB})\end{array}$ \\
\hline 增幅器 & $\begin{array}{l}4 \text { チャネル+時計チャネル } \\
60-96 \mathrm{~dB}(7 \text { 段階 }) \\
\text { 周波数: } 1-100 \mathrm{~Hz}(-6 \mathrm{~dB}) \\
\text { 電力: } 186 \mathrm{~mW}\end{array}$ & $\begin{array}{l}11 \text { チャンネル } \\
50-90 \mathrm{~dB}(3 \text { 段階 })\end{array}$ \\
\hline 時計 & $\begin{array}{l}\text { 精度: } \pm 5 \times 10^{-7} \text { 以内 } \\
\text { 電力: } 35 \mathrm{~mW}\end{array}$ & $\pm 5 \times 10^{-7}$ 以内 \\
\hline 電 源 & 電池：アルカリ単 1,34 本 & 電池: リチゥム, ニッカド, 20 本 \\
\hline 耐圧容器 & 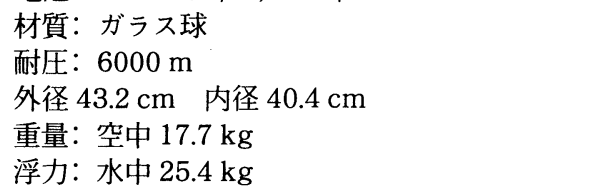 & $\begin{array}{l}\text { アルミニゥム }(\mathrm{A} 7178-\mathrm{T} 6) \\
6000 \mathrm{~m} \\
\text { 外径 } 75 \mathrm{~cm} \quad \text { 内径 } 72.5 \mathrm{~cm} \\
\text { 空中 } 230 \mathrm{~kg} \text { (含重り }) \\
\text { 水中 } 25 \mathrm{~kg}\end{array}$ \\
\hline $\begin{array}{l}\text { 切り離し } \\
\text { 重 り }\end{array}$ & $\begin{array}{l}\text { 方式：音響命令による強制電蝕/タイマー } \\
\text { 鉛 } / 32 \mathrm{~kg}\end{array}$ & $\begin{array}{l}\text { 音響命令による火薬/タイマー } \\
\text { 鋼 } / 65 \mathrm{~kg}\end{array}$ \\
\hline 発見回収 & $\begin{array}{l}\text { トランスミッタ, フラッシャ } \\
\text { 北大/東大理 }\end{array}$ & $\begin{array}{l}\text { トランスミッタ, フラッシャ } \\
\text { 千葉大理 }\end{array}$ \\
\hline センサー & $\begin{array}{l}\text { 上下動 }(3 / 4.5 \mathrm{~Hz}) 1 \text { 成分 } 3 \text { チャネル } \\
\text { 水平動 }(4.5 \mathrm{~Hz}) 2 \text { 成分 } 3 \text { チャネル } \\
\text { ハイドロホン: (オプション) }\end{array}$ & $\begin{array}{l}(4.5 \mathrm{~Hz}) 1 \text { 成分 } 3 \text { チャネル } \\
(4.5 \mathrm{~Hz}) 2 \text { 成分 } 3 \text { チャネル } \\
\text { OASE-2SD (DC- } 5 \mathrm{kHz})\end{array}$ \\
\hline $\begin{array}{l}\text { 方 位 計 } \\
\text { 記 録 器 }\end{array}$ & $\begin{array}{l}\text { (オプション) } \\
\text { カセットテープ直接アナログ記録 }\end{array}$ & $\begin{array}{l}\text { (オプション) } \\
\text { カセットテープ直接アナログ記録 }\end{array}$ \\
\hline & $\begin{array}{l}\text { 速度: } 0.05-0.13 \mathrm{~mm} / \mathrm{s}(11-25 \text { days } 90 \mathrm{~min} \\
\text { tape) } \\
\text { 周波数： } 1-30 \mathrm{~Hz}(-3 \mathrm{~dB})(11 \mathrm{day})\end{array}$ & $\begin{array}{l}0.05-0.13 \mathrm{~mm} / \mathrm{s}(11-25 \text { days } 90 \mathrm{~min} \text { tape }) \\
1-30 \mathrm{~Hz}(-3 \mathrm{~dB})(11 \text { day })\end{array}$ \\
\hline 増幅器 & $\begin{array}{l}6 \text { チャネル+時計チャネル } \\
40-84 \mathrm{~dB} \\
\text { 周波数: } 0.6-100 \mathrm{~Hz}(-3 \mathrm{~dB}) \\
\text { 電力: }\end{array}$ & $\begin{array}{l}6 \text { チャネル十時計チャネル } \\
62-90 \mathrm{~dB} \\
0.6-100 \mathrm{~Hz}(-3 \mathrm{~dB})\end{array}$ \\
\hline 計 & $\begin{array}{l}\text { 精度: } \pm 5 \times 10^{-7} \text { 以内 } \\
\text { 電力: 数 } \mathrm{mW}\end{array}$ & $\pm 5 \times 10^{-7}$ 以内 \\
\hline 電 源 & $\begin{array}{l}\text { 電池: アルカリ単 } 1,12 \text { 本 } \times 2 \\
\text { リチウム } 2 \text { 本 } \times 2\end{array}$ & $\begin{array}{l}\text { アルカリ単 } 1,20 \text { 本 } \\
\text { リチウム } 7 \text { 本 }\end{array}$ \\
\hline 耐圧容器 & 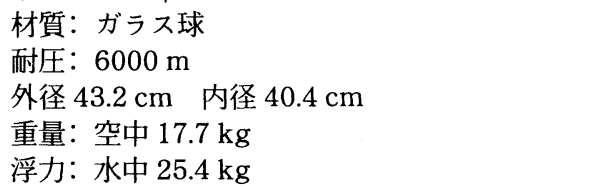 & $\begin{array}{l}\text { ガラス球 } 2 \text { ケ } \\
6000 \mathrm{~m} \\
\text { 外径 } 43.2 \mathrm{~cm} \text { 内径 } 40.4 \mathrm{~cm} \\
\text { 空中 } 17.7 \mathrm{~kg} \times 2 \\
\text { 水中 } 25.4 \mathrm{~kg} \times 2\end{array}$ \\
\hline $\begin{array}{l}\text { 切り離し } \\
\text { 重 り } \\
\text { 発見回収 }\end{array}$ & $\begin{array}{l}\text { 方式：音響命令による強制電蝕 } \\
\text { 鉄/40 k } \\
\text { トランスミッタ, フラッシャ }\end{array}$ & $\begin{array}{l}\text { 音響命令による強制電蝕/タイマ } \\
\text { 鉄/80 kg } \\
\text { トランスミッタ, フラッシャ }\end{array}$ \\
\hline
\end{tabular}

性，迅速性から自由落下させて観測終了後船からの音響 信号あるいは時刻設定によりおもりを切り離し，浮上さ せて回収する自己浮上式がほとんどである.

海底に設置するには海水の圧力をまず考えなくてはな
らない，すなわち種々のユニットを収める耐圧容器が必 要になるが，形としてはシリンダー型か球型に分かれ る. 17 インチ直径のガラス球の利用が海洋での計測に 広く使用されていてもっとも廉価である.ひとつの耐圧 
容器にすべて収める場合ああるし，分離する場合 [BYRNE et al. (1983)] もある. 前者は容器内加のノイ ズに, 後者は複雑さが増すので信頼性に気を付けなくて はならない，容器のかたちも観測デー夕の良否につなが るのでおろそかにはできない。

世界でもむっとも小型計量の OBS は構成する部分を すべて収めてまわりに打ありとその切り離し装置，そし て海面に浮上したとき発見を早めるためのフラッ シャー, ビーコンをつけたパッケージで, 人間 2 人で取 り扱える [山田 (1980)]。船を選ばず, 場合によってはへ リコプターから設置することもできる．機動的な小さい 自己浮上型 OBS はひとつの思想の具現化といえる。 た だし日本近海のように水深 $7,000 \mathrm{~m}$ を超える場所が少 なくない所では, 而圧の点から別の夕イプも必要にな る.

\section{3 センサー}

センサーがハイドロホンなら ( $\mathrm{OBH}$ と呼ばれる) 水中 で圧力変化を検知するので海底に接する必要はない。 カップリングを気にしなくてすむ. S 波を含めて 3 成分 測るには陸上用の地震計を流用してジンバル機構により 保持することが多い。好じれ，回転などは測っていない． ハイドロホンと併用すると， P, S の峻別が容易になる. 方位はまず不明の場合が多いが，人工震源による信号か ら推定すること [DUENNEBIER et al. (1987), NAKAMURA et al. (1987)]， あるいは積極的に方位計を工夫して備え ることあある.

\section{4 記録方法}

記録方法は限られた電力で最大の容量を確保する工夫 でバラエティーが生まれる。記憶媒体としてもっとも安 価でしかも大量の記録が可能なのは，カセットテープの 直接アナログ記録である [例えば笠原・他 (1979), 山田 (1980)].これは工夫に工夫を重ねて,レコーダ 1 台で 1 ヶ月観測（4 成分）できるようになった。ダイナミック レンジは調整によるところがあるが $40 \mathrm{~dB} /$ チャンネル 程度なのでふつうは 1 成分多チャンネルにしてこれを 補う．例えば， 2 台並列作動させ 7 チャンネルの記録を 取ること屯可能になり多成分観測でかつダイナミックレ ンジの確保ができるようになった［金沢(1986)].

ディジタル記録をおこなうと容量を犠牲にせざるを得 なくなるうえ電源確保がむつかしくなる．したがって連 続記録はあきらめ, イベント駆動方式か時間枠方式を採 用している. カートリッジテープを利用したいくつかの 例のうち 50 メガバイト記録できるのが KASAHARA et al. (1985) により開発されたものである. 間欠的に記録 するイベント駆動方式およびデー夕を圧縮する ADPCM 方式により記録容量の増大を図っている，1点

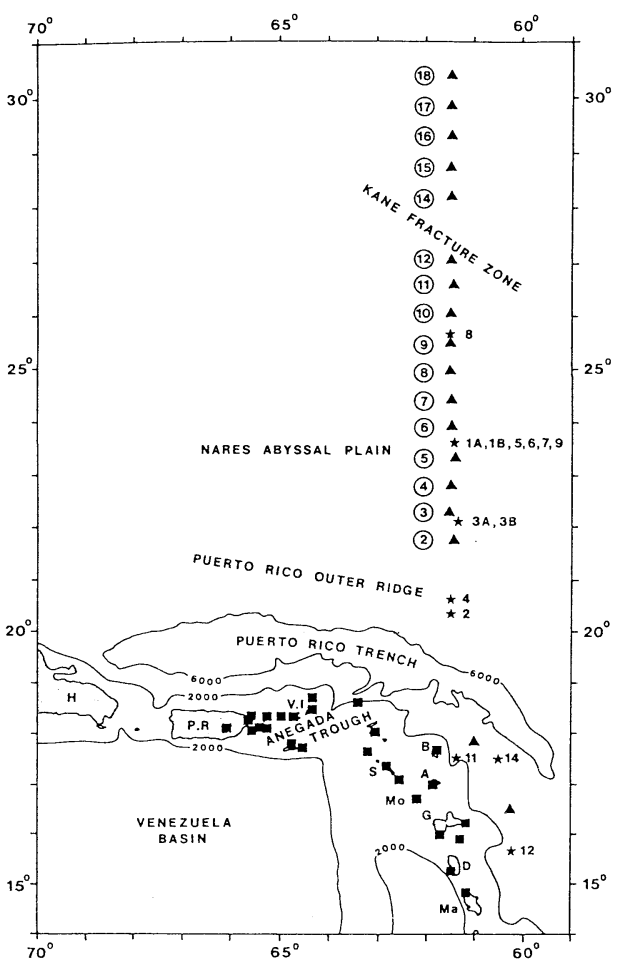

Fig. 3. Geometrical experiment design of LADLE Study Group (1983). Shots (asterisks), OBSs (triangles), and island stations (squares) are shown. Their objective was to study the lithophere structure in the Atlantic encouraged by the Japanese results in the Pacific.

のみの観測で欲しいイベントだけ検出することは難し い. 人工地震による構造調查に的を絞って 5 メガバイト の容量に決められたタイムウィンドゥのデータのみ記録 する方式あある [NAKAMURA et al. (1987)]. これで50 $\mathrm{m}$ 間隔に人工地震を起こして必要なデータだけ記録す ると $60 \mathrm{~km}$ 余りの測線分になる.

\section{5 電 源}

電源確保は現在のところ, 気象庁の行っているような ケーブル式以外は電池に頼っている. あっと屯多い夕イ プは, 而圧容器に収められた乾電池 (アルカリマンガン, リチウム) である。これで時計, エレクトロニクス, 記 録器を維持する. 消費電力はしたがって, 最低に抑える 工夫が凝らしてある. 例えば防災科学技術センタ一開発 の自己浮上型 OBS は音響トランスポンダーを含めて $120 \mathrm{AH}$ で 40 日間アナログ連続記録を実現している [FuJinAwA et al. (1987)]. より小型のガラス球を使った OBS はさらに消費電力を抑えて 1 ヶ月程度の連続観測 が可能である [例えば金沢 (1986)]. 


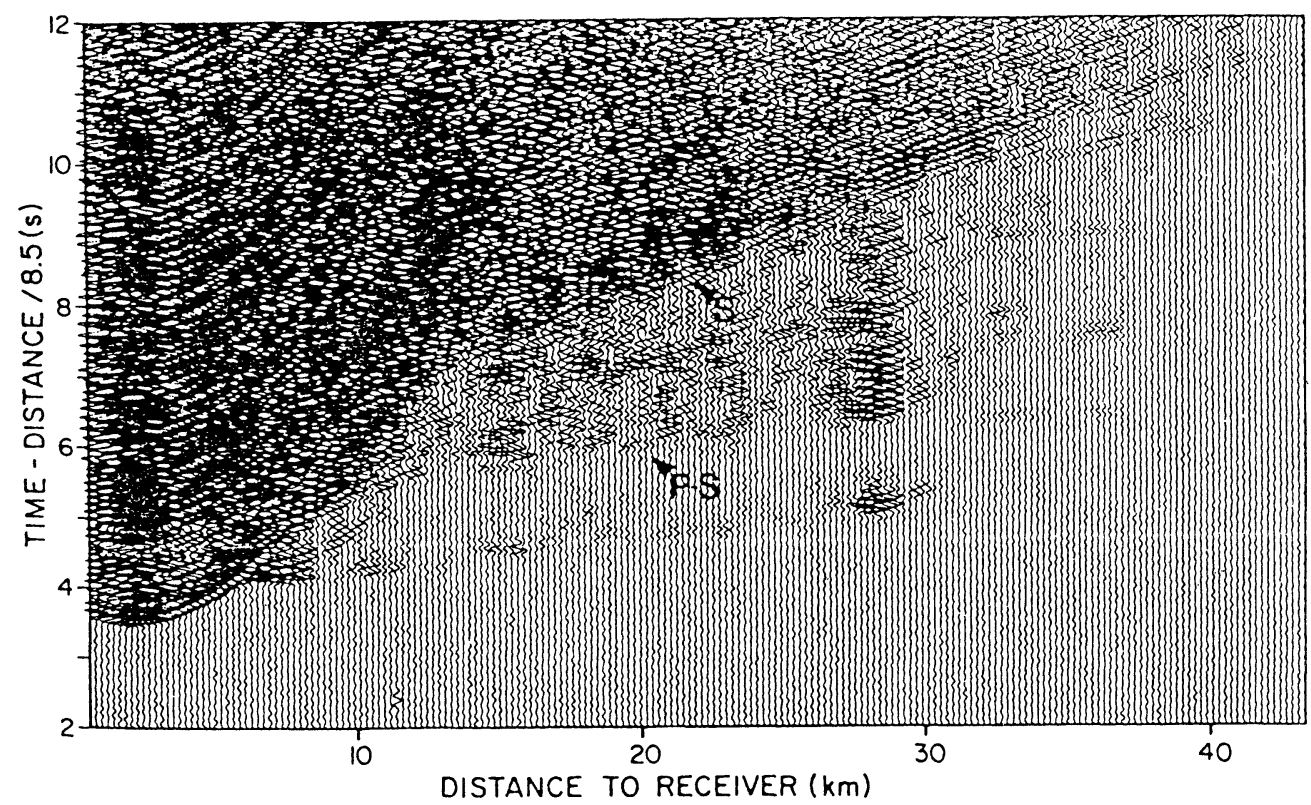

Fig. 4. An example record of airgun shots obtained by OBS 15 (vertical component) (Fig. 3) [from LADLE Study Group (1983)]. Shot spacing is about $200 \mathrm{~m}$. Note the presence of later arrivals indicated by arrows. $\mathrm{P}-\mathrm{S}$ is $\mathrm{S}$ converted phase converted at sediment/basement boundary. S wave is also observed to bring shear wavespeed information.

\section{§3. 1980 年代の海底地震観測一ケーススタディー} 3.1 リソスフィアの構造

リソスフィア規模の構造研究は日本では長距離爆破地 震観測を実施してきた長い歴史があり，ほとんど独壇場 の感すらある [AsAdA and SHimamURA (1979), Nagumo et al. (1981), Asada et al. (1983), Shimamura et al. (1983), 末広 (1987)]. ここでは, しかしあえて外国 の研究の例を見よう.

深部からの屈折波を捉えるには長距離の測線を要す る. 簡単にできる実験ではない。しかあおおまかな構造 は既知として地域性, 異方性といった問題に挑戦するの であるからたくさんの測器を動員する大きな共同研究に なる. 太平洋での日本の成果をみて大西洋リソスフィア (80〜95 Ma) の構造研究に挑戦したのは LADLE STUDY GROUP (1983) である (Fig. 3). 小アンチル島弧にあ観測 点を展開している. $\mathrm{S}$ 波源であありエネルギーも大きい 自然地震もできるだけ利用するためであある，1 ヶ月の 観測期間を維持して $1,500 \mathrm{~km}$ の震央距離で自然地震を 10 ヶ程度捉える計画であった. OBS は約 1 週間の記録 容量の型がほとんどなので 2 船を用いて回収設置を繰 り返した，長い測線をとろうとすると，大きな海底地形 変化を避けるのはむつかしく, この場合はケイン破砕帯 をまたいだ。

人工震源は自然地震と異なって制御がきく，震源の位
置, 発震時刻そしてスペクトルを既知とし, かつ制御し たいわけであるが, 自由自在というわけにはいかない. 火薬による爆破の位置は, 船と火薬間に距離をおく必要 があるので, 数 $100 \mathrm{~m}$ の誤差が入り込みうる. 時刻は電 気発破なので船の持つ時刻精度と同じである。これが導 火線方式だと火薬の近傍にハイドロホンを置いて信号を 船まで電波で飛ばす。爆破時刻推定に水中音波 $(1.5 \mathrm{~m} /$ $\mathrm{ms}$ ）利用をなるべく避けることがポイントである. 発破 深度はふつうききをよくすること（海面上にエネルギー が逃げないようにする；海面反射波と位相が合うように する）を考える. しかし総合的には, 地震波経路の減衰, 雑音のスペクトル，OBS の特性も考慮しなければなら ない。

この実験では分散発破を用いて信号の卓越周波数が 3 $\mathrm{Hz}$ になるよう制御している. 爆破はその重さ（薬量）に よって生成される気泡の振動, したがって信号の卓越周 波数が決まる. エネルギーを高めつつ，周波数（波形） を制御するために考えられたのは爆薬を数個に分けてお のおのから気泡を同時に発生させる方法である $\left[\mathrm{J}_{\mathrm{ACOB}}\right.$ (1975)].このようにすると距離をおいて分離させた個々 の爆破による信号スペクトルの和が全体になる，さら に, エネルギー的にも薬量の $2 / 3$ 乗に比例するので分離 させて信号を重ね合わせた（和にする）方が効率が良い。 あと考慮すべきは，観測波形を議論するとき震源が点震 


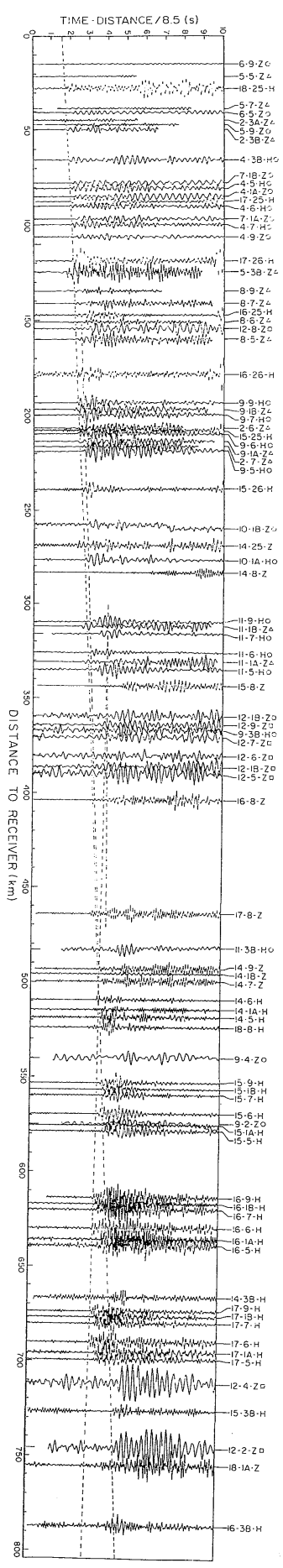

Fig. 5. OBS record section of explosives by Ladle Study Group (1983). Compare the change in scale from Fig. 4.
源と考えてよいかということである.

エアガンも人工震源として利用している. エアガンは 火薬と異なる点は, 高圧空気 $\left(100 \sim 150 \mathrm{~kg} / \mathrm{cm}^{2}\right)$ を作 れば，何発であうてることである. たくさんうてること は個々のショットのエネルギーは小さくとも, 空間的に 密なデータが得られるので, 内部構造の解像度が上が る. 波形制御の事情は火薬と同様である. 単体で大容量 よりいくつも連ねたアレーの方が効率がよくフレキシブ ルと言える.

この実験では 32 リットル容量のエアガンを $200 \mathrm{~m}$ おきにショットして北部の地殼構造を調べている (Fig. 4). 爆破観測の記録を Fig. 5 に示す. Fig. 4 と F ig. 5 の 違いに, 人工震源としてのエアガンと火薬の違いが現わ れている. 火薬による記録は異なる発破, 異なる OBS によるものを集めている. $800 \mathrm{~km}$ 以遠は初動がはっき りせずデータも少ない. 波形の違いはおもに OBS の特 性, 海底とのカップリングによると考えられる.

結果を詳しく紹介することは目的でないが，この規模 の実験で $60 \mathrm{~km}$ 程度の深さの構造の議論ができる (Fig. 5). リソスフィア下部で $8.55 \mathrm{~km} / \mathrm{s}$ と高速度になること が特徴である.

太平洋ではハワイ大学がウェーキ島周辺のハイドロホ ンアレー観測による研究を続けてきた [例えば W ALKER and MCCREERY (1985)]. 1982 年にはウェーキ島をま たいで北西一南東 OBH 12 台で $1,600 \mathrm{~km}$ のアレーを設 置して自然地震を利用した構造研究を行った [BUTLER (1985)]. 当然観測期間が問題となるが，この場合 65 日 間，全点共通には20日間であった。 この間に千島弧か らマリアナ弧に至る島弧部に発生した 16 ヶ $(M>4.9)$ の地震を解析対象として, P, S 波の異方性存在が大規模 であることを日本の結果 [Shimamura (1984), ShimaMURA et al. (1983)] に続いて示唆した. 適当な自然地震 を捉えるためには長期観測が必要であることが分かる。

\section{2 中規模構造（多点高密度観測）}

Fig. 6 が如実に物語るように, 時代は多点高密度観測 を中規模構造に向けることができるようになった [IwASAKI et al. (1990)]. 1984 年の日独共同で実施された琉 球海溝の実験では延べの OBS 動員が 37 台, 火薬が大小 $(200,25 \mathrm{~kg})$ あわせて 12 トン 415 発であった. OBS は 約 $10 \mathrm{~km}$ の間隔に設置, 小火薬は 5 分 (約 $1.5 \mathrm{~km}$ ) 間 隔で航走しながら電気発破した。この共同実験のもとの 計画では，さらに詳しく広がりを持った構造を明らかに する予定であったが， OBS の亡失などで一部縮小され た.それでも，この琉球海溝断面図はほかに例を見ない 解像力を深部まで持っていることをはじめて示した (Fig. 6). 


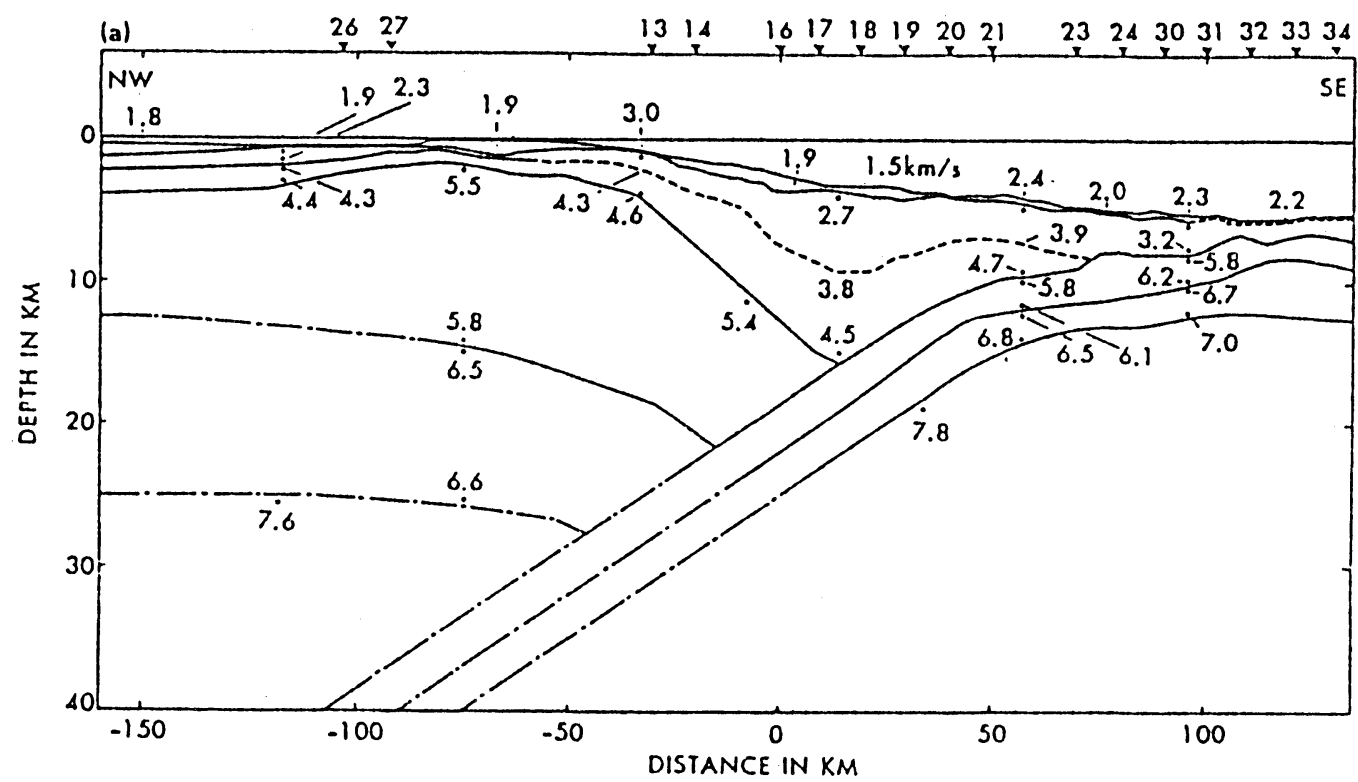

Fig. 6. P-wavespeed model across the northern Ryukyu Trench as obtained by IwASAKI et al. (1990). Multi-OBS observation is necessary to define the laterally heterogeneous structure at this scale. Interface in solid line is where wavespeed jumps. Chain lines are extrapolations that agree with gravity data. Vertical wavespeed gradient is smaller below the dotted line interface. Thick sedimentary wedge is the outstanding feature at this trench system.

共同実験は，互いに蓄積してきた実績あるノウハウを 交換しあえると $100 \%$ ねらいどおりでなくとあ将来へ の刺激が大きい，日本では琉球海溝の実験の後, 電気分 散発破があたりまえになった。 アンカードブイ方式で あったハンブルク大学の $\mathrm{OBH}$ は自己浮上方式へと改良 された.

\section{3 地款内部（精密微細構造）}

数少ない大規模構造研究が行われている間, 細かい構 造にあ目は向けられていた。 むしろこちらが主流であっ た。プレート沈み込みの場である日本では海溝軸周辺の 高い地震活動と構造の関連を探るための人工震源と OBSによる実験が重ねられた [例えば SUYEHIRO et al. (1985), Nishizawa and Suyehiro (1986)].

一方欧米はプレート生産の場である海嶺に幾度も足を 運んだ。東太平洋海嶺 (EPR) は ROSE 計画（表 1) [EWING and MEYER (1982)] が華々しかったが, その後 あメスはいれ続けられてきた．解像力を上げないことに はマグマチェンバーの形, 地震構造, 年代との関係が明 らかにできず，したがって海底の割れ目，ブラックス モーカー, 水循環との関連む分からず, プレート生成の ダイナミクスにもせまれないわけである，MAGMA 計 画 [MCCLAIN et al. (1985)] はデジタル OBS [MOORE et $a l .(1981)]$ を $16 \mathrm{~km}$ の幅にあたる年代 0, 0.1, 0.3 Ma の 3 点に 2〜 4台づつ設置し, 火薬ショットを小スケール
(15〜17 km) グリッドで $230 \mathrm{~m}$ 毎に 450〜1,350 g づ つ, 大スケール $(60 \mathrm{~km})$ グリッドで $950 \mathrm{~m}$ 毎に 7 109 $\mathrm{kg}$ づつ計 2,003 発爆破させた. 2 次元的な解析では海 嶺直下 $(1.1 \sim 5.1 \mathrm{~km})$ の幅 $6 \mathrm{~km}$ 以内のマグマチェン バーが存在するモデルが妥当とされたがユニークとはい えなかった [McClaIN et al. (1985)]. ほんとうにマグマ チェンバーは小さいのか, HARDING et al. (1989) はほぼ 同じ海域で OBS を使わないマルチチャネル反射法の拡 張版である 2 船法 [STOFFA and BuHL (1979)] で調べた. 結果はかならずしも矛盾しないがモデルの示す低速度領 域のかたちは異なる解釈を生んであ不思議ではない。重 要なことは 2 船法の方がデー夕の空間密度が高くモデ ルの制約度が高いことである．2 船法は準備す費用もお おがかりになる。しかし海嶺ではこのくらい解像力を上 げないとグローバルな問題であるプレート生成問題を解 き明かすことができないのである.

海底に受波器のみ置くのではなく, 人工震源も置けれ ば海底下構造の解像度は上がる。このための努力む払わ れてきた [Dorman et al. (1986)]. 最近, PURdy (1987) は海底上部 $100 \mathrm{~m}$ 以内を曳航しつつ 48 発 $(2.3 \mathrm{~kg} /$ 発 $)$ 連続発破できるシステム (DETES) [KoELSCH et al. (1986)］を用いた研究を行った。これを大西洋中央海嶺 で実施して海底下わずか $200 \mathrm{~m}$ までの速度とその勾配 を推定した（年代 $0 \mathrm{Ma}: 2.1 \mathrm{~km} / \mathrm{s}, 4 \mathrm{~s}^{-1} ; 7 \mathrm{Ma}: 4.1 \mathrm{~km} /$ 


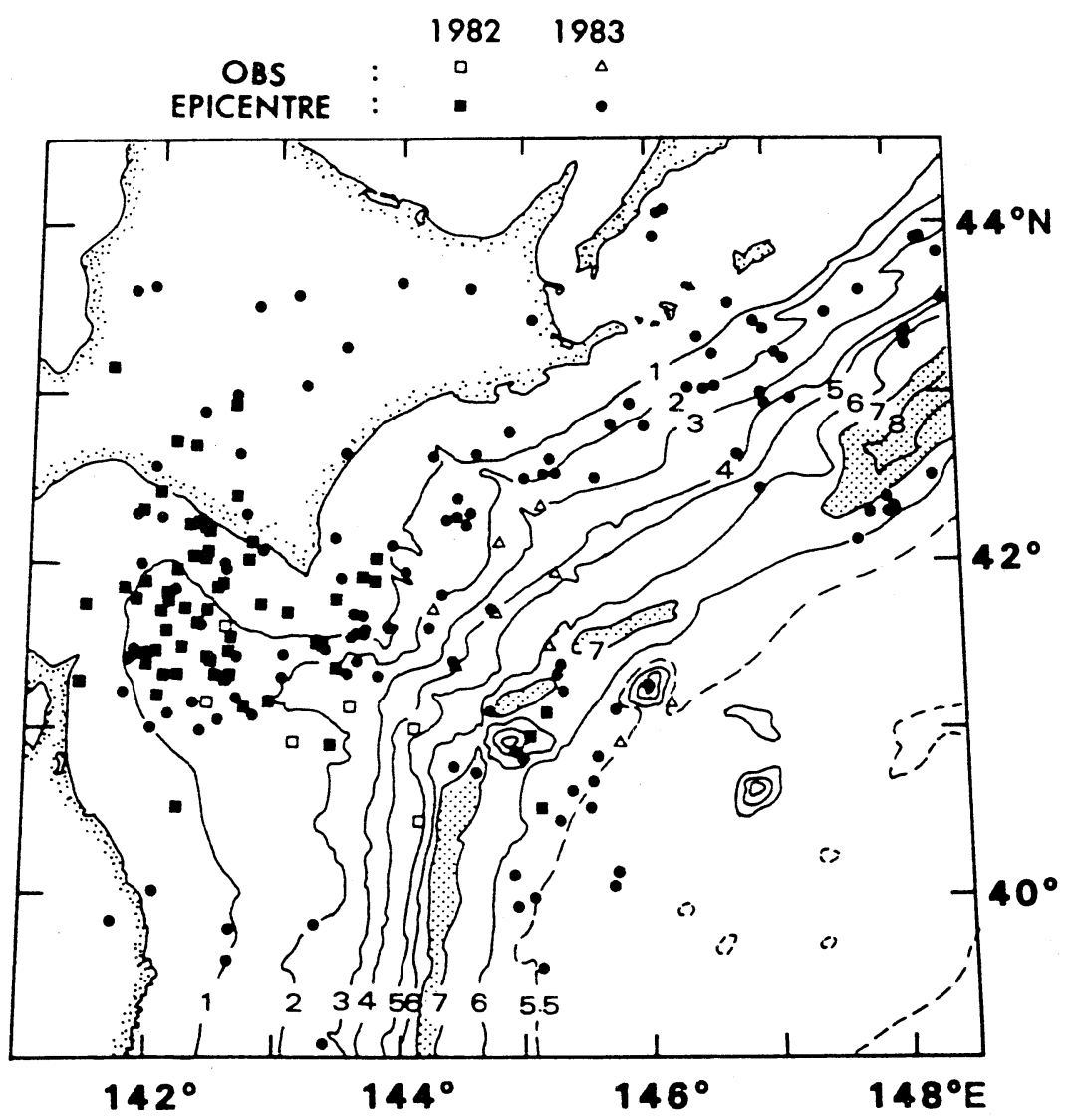

Fig. 7. Seismicity map of the Japan Trench area [from Hirata etal. (1989)]. Epicenters from two temporary observations in 1982 and 1983 are shown with OBS-array locations. Note the aseismic band along the inner trench wall and the activity seaward of the trench axis.

$\left.\mathrm{s}, 0.5 \mathrm{~s}^{-1}\right)$. このような精度の結果は上記海嶺の例にこの まま応用するにはエネルギー不足であるが，深海掘削の 資料，ロギングの結果との比較を可能にする.

深海掘削計画 (DSDP/IPOD/ODP) の掘削孔内の異な る深度に地震計をクランプして，周辺の人工地震を捉え て地款の浅い構造を精査した例もだいぶん蓄積した［例 えば SwIFT and STEPHEN (1989)]. 掘削のためのドリル パイプの存在は雑音を大きくするし，ケーシングが入っ ているとそこを伝わる波に邪魔される，ということがあ るが，地壳内部の精密構造，異方性に重要なてがかりを 与えてくれる.この実験は掘削船とシューティングを行 う船と 2 隻要する。一方，すでに掘削された孔内に再突 入する技術は開発されつつありフランスは成功した [LEGRAND et al. (1989)]. 孔内そのものは雑音が低いと 期待されるので今後が楽しみである.

\section{4 自然地震}

サイスミシティを求めるより突っ込んだ研究は少ない [Frohlich et al. (1982), TREHU and Solomon (1983)].
OBS 記録から振幅の情報を取り入れて議論をするよう になったのは最近である. さらに波形となると, 後述す るノイズ, カップリングの問題があり，そもそも短周期 の「空」で見ているのでむつかしい，短期間の観測によ る即戦型であるので, ねらいは微小地震, あるいは大地 震の余震である，運がよければ，グローバルに観測され た地震を捉える [DUENNEBIER (1987), SUYEHIRO et al. (1988)]. 運にたよってばかりはいられないので長期観測 を合目的的に設計しなくてはならない.これは今後の最 大の課題である.

日本周辺でのサイスミシティの特徴は何回かの観測で 再現された [例えば KASAHARA et al. (1982), HIRATA et al. (1989)] (Fig. 7). Fig. 7 にあらわれた地震発生の ギャップ, 海溝軸海側の活動は, 南北に長い日本の陸か らの観測のみではどうしても深さと東西方向の精度を押 さえるのがむつかしく, OBS 微小地震観測によって明 らかになった。

迅速性を要求される余震観測ではへリコプターの出動 
あある [URABE et al. (1985)]. デー夕回収は船に頼らな ければならない，設置場所，ゲイン設定などは陸上観測 と同じ考え方である.ただし大きくレイパラメー夕の異 なる波を観測する陸上との連係を考慮することも重要で ある. デー夕処理では異なる OBS のデー夕を陸上のテ レメー夕記録と同様に同じ時間軸で一覧できることが読 み䛊りを減らし精度を上げる [卜部・平田 (1984)].

\section{§ 4. 海底地震観測の問題}

\section{1 時 刻}

オフライン観測の場合, 時刻精度は OBS 内の水晶発 振器の特性によって決まる. 実験の性格によるが, 例え ば 0.1 秒の精度で 1 ヶ月観測したいということは $4 \times$ $10^{-8}$ 精度の水晶発振器を用いたいことになる. 普通は ここまで精度の良い水晶発振器はあまり使われない，5 $\times 10^{-7}$ 程度なら手に入りやすくいわば標準である [INATANI and FURUYA (1980)]. この精度はある温度範囲に 成り立つ数字で海底のように温度がほとんど一定の環境 ではさらに良いことが期待できる. あうひとつ経年効果 (エージング) を示す数字ああり, 1 年間で $5 \times 10^{-7}$ とい うように表すが温度効果の方が大きいのが普通である.

観測開始前後に時刻補正を行ってその補正值を線形補 間して観測期間中の時刻を推定するのが普通である。そ れぞれの水晶発振器の個性は実験室で測定, 調整してお くことが精度向上につながる.

絶対時刻は, 標準時の放送を捉えるか, 捉えられない ような海域のためには特に精度の良いマスタークロック を船上に置いておく，最近は船の位置決定用に高精度の 時計が積まれていることが多いし, 位置決定用の軌道衛 星から時刻を得ることもできる.

1 ヶ月を大きく超えるオフライン長期観測では, 時刻 精度は大きな問題である.これについては人工地震を利 用したインバージョンにより観測期間中の時刻補正をし た例がある [NAKAMURA et al. (1987)].

\section{2 位 置}

緯度, 経度, 水深がパラメータである. 問題は二つ あって, ひとつはとにかく正確にこのパラメータを決定 することである. あう一つは，置きたいところに置くと いうことである.これは自動的にどこに置きたいか知っ ていることを要求する.

船の位置の正確さがまず重要である．これは GPS の 登場で大きく改善されつつある. 海域, 時刻 (電波状況) によるが, 地上発信電波により常時受信できるロランC では $1 \mathrm{~km}$ 以内程度, 1 時間 1 回程度決定できる衛星電 波の利用では数百 $\mathrm{m}$ 以内であった状況が GPS 衛星によ り常時百 $\mathrm{m}$ 以内の精度が確保できつつある. また, 陸地
から $100 \mathrm{~km}$ 以内程度なら陸上に臨時電波局を設置し て $10 \mathrm{~m}$ 以内の精度を確保できる.こうなってくるとそ あそも緯度経度がどの測位系に基づくものか明確にして おかないと後で混乱する.

しかし，船の位置すなわち自由落下させた OBS の海 底での位置というわけではない，海底での位置を決める には音響測位を要する。これは時間の制約もありまだあ まり実行されていないが計画した実験の要求する精度に よっては, 必要になる.

南雲・他 (1982) が自己浮上式 OBS の位置決定の方法 と精度を述べている. OBS 投下を衛星航法 (NNSS) で決 められた時刻に行うこと, 回収を浮上後速やかに行い浮 上位置と回収位置のずれを小さくしておく，回収位置は 電波航法（おむにロランC）によって決めるので衛星航 法位置とのみかけのずれを補正できるようにしておく. OBS 位置は投入位置と回収地点の中間点とすれば衛星 航法位置に対し $0.2 \mathrm{~km}$ 以内の精度で決定できうるとし ている.

CREAGER and Dorman (1982) は，音響測位を用いた 決定による精度を 3 つの実例によって示している. 精度 は衛星航法の位置の精度も含めて $100 \mathrm{~m}$ 程度になる.

置きたいところに置くために OBS を船からワイヤで 吊るして降ろした例もある[CREAGER and DORMAN (1982), DoRmAn et al. (1988)].これは船の操縦性能がよ くなければならないし, 船の移動とワイヤ下部の移動は 数 10 分のずれを伴うので根気がいる. 潜水艇で設置で きれば，陸上の場合とかなり似る [ShIMAMURA and KANAZAWA (1988), 筒井・他 (1989)]. 目的は岩盤, 断 層など海底地質のわかっているところに置く，あるいは OBS を数台近接させて置いてアレーを構成する，いず れあ地震波からより多くの情報を得ようとするあのであ る.

\section{3 カップリング}

カップリングとは地震計と設置点との機械結合のこと である.ほとんどの場合柔らかい堆積物の上に設置する ことを余儀なくされる海底地震観測は当初からカップリ ングが問題となった [SUTton et al. (1965, 1981), TREHU (1985), Sutton and Duennebier (1987)]. OBS がない ときの海底の振動をそのまま OBS の存在が影響しない ように記録したいのである. 仕様が似ている以上だれの OBS であ同じ場所なら似た記録を書かなくてはならな い.しかしなかなかそうはいかない[SUTton et al. (1981)].

OBS と柔らかい堆積物は質量, バネ, ダッシュポット の系とみることができる [TREHU (1985)]. バネと減衰定 数は OBS のかたちと堆積物の物性（とくに剛性率）に 
よる. 問題はカップリングによる共鳴を観測周波数外に 追いやることと減衰の効果を高めることである. しか し，いくつかの実験の結果はまだ理論どおりでない不明 の点を残している [南雲 (1980), SuTToN et al. (1981), TREHU (1985)].

やわらかい堆積物をさけるために深海掘削計画による 掘削孔利用は何度か試みられている [OSS; 例えば BYRNE et al. (1987), MSS: 例えば HARRIs et al. (1987), 最近は INGLE, SUYEHIRO et al. (1990)]. しかし, 機会が なかなかない，掘削船を利用せず掘削済みの孔に再突入 (リエントリー) するには, まず再突入可能な孔が必要で あり再突入の技術開発も必要である [STEPHEN et al. (1987), LANGSETH and SpIEss (1987), LEgRAND et al. (1989)]. 露出した岩盤を捜して設置するには, 場所が当 然限定される. より簡便な方法に OBS を堆積物中にも ぐらせるというのがある [TuRGuT et al. (1987)]. 彼らの システムは浅海用だが海底面より $75 \mathrm{~cm}$ もぐらせたも のがそうでないものより水平動長周期成分に大きく改善 がみられた（数秒周期以上で $20 \mathrm{~dB}$ ).

\section{4 ノイズ}

雑音はカップリングとは別問題の, しかし観測波形を ゆがめる重要な問題である. 雑音は, たとえばテープ走 行系のように OBS 内部に起因するものと外部に起因す るものとに分けられる. 内部雑音と切り離すためにセン サーだけ分離させても, 記録器を持った部分が摇れてい たらその振動が海底を介して伝わるであろう [PROTHERO (1984)].

外部と言っても OBS の設計に関わるあのとまさに自 然の雑音がある. 前者は, たとえば回収のときに発見用 に用いるビーコンのアンテナが底層流でふるえる雑音が ある [笠原・他 (1980)]. OBS のバランスが悪いと, 水 平に摇らしても傾きを生じる. カップリングが悪くても 同様である. 自然の雑音は微動に代表される. また流体 である海水, やわらかい堆積物, そしてでこぼこの基盤 面の存在は, 多重反射波, 変換波, 表面波（ストンレー 波）を複雑に重ね合わせることになる.

このようにいくつあの異なる原因があり, さらに気象 条件, 地域性（陸に近い遠い）手加味される。したがっ て，ただ単に地震のないときのスペクトルをやみくもに 調べてああまり得るところがない，因果関係を調べてい かなければならない.

\section{§5. 1990 年代の海底地震観測}

今後の大きな達成目標は, 自然地震を対象にした長期 定点観測であり，広帯域観測である．いずれも大洋底で はまだなのである．走時だけにねらいを絞れば従来型を 長期用にすればよい. しかし自然地震による実体波の波 形, あるいは表面波, 自由振動データによる議論のため には冒頭にも触れたように観測の「空」を広げる努力が 必要である (Fig. 1), 陸上の広帯域高性能地震計はデジ タル帰還型センサーにより「空」を広げた，海底への応 用での難点は電力供給が必要になることである．姿勢制 御も長周期まで考慮した設計が必要になる。ここ数年内 に実験が実行中 [INGLE, SUYEHIRO et al. (1990)], 計画中 [PURdy and DzIEwonski (1988)] である.しかもこれを 多点にしなくてはならないという課題を抱える. ネット ワークの規模としてはリソスフェアに注目すれば現状よ り数倍良い縦 $(25 \mathrm{~km})$ 横 $(100 \mathrm{~km})$ 方向の解像力を確保 すればリソスフェアの不均質性, 異方性の意味を考える ことができる [例えば LERNER-LAM (1988)].さらにオ フライン観測ではデー夕回収と電源確保の問題がある. 地震データは大量（1 秒 100 サンプル 16 ビット 3 成分 見たい $(4,800 \mathrm{bps})$ とすると，1 日で 50 メガバイトにな る）で,これを衛星で運ぶのは不可能ではないが高価に なる. 海底から海面へデータを運ぶことも未解決であ る.

一方，プレート境界に見られるさまざまの現象を正確 に捉えるには海底地震観測の精度をまだまだ上げる必要 がある.たとえば海底堆積物の構造研究は反射法による 高空間密度, 高周波データをもとにした研究が圧倒的で あり，まだ海底地震観測の威力が発揮されていない。

アレー観測は, 地震波のみかけ速度 (レイパラメータ) を直接求める有効な方法だが海底での位置の精度が高く なれば, 例えば速度フィルターによるノイズ分離も可能 になり, 有効であろう. OBS 観測は, 例えば, 数 $10 \mathrm{~m}$ 毎に人工震源を置いた数 $10 \mathrm{~km}$ 測線, あるいは全長 $1,000 \mathrm{~km}$ を超える測線による構造研究など陸上では達 成不可能に近い観測が可能であり，この方向の展開も重 要である.

\section{謝辞}

初めの段階で詳しく目を通してくれた金沢敏彦氏に感 謝します。 


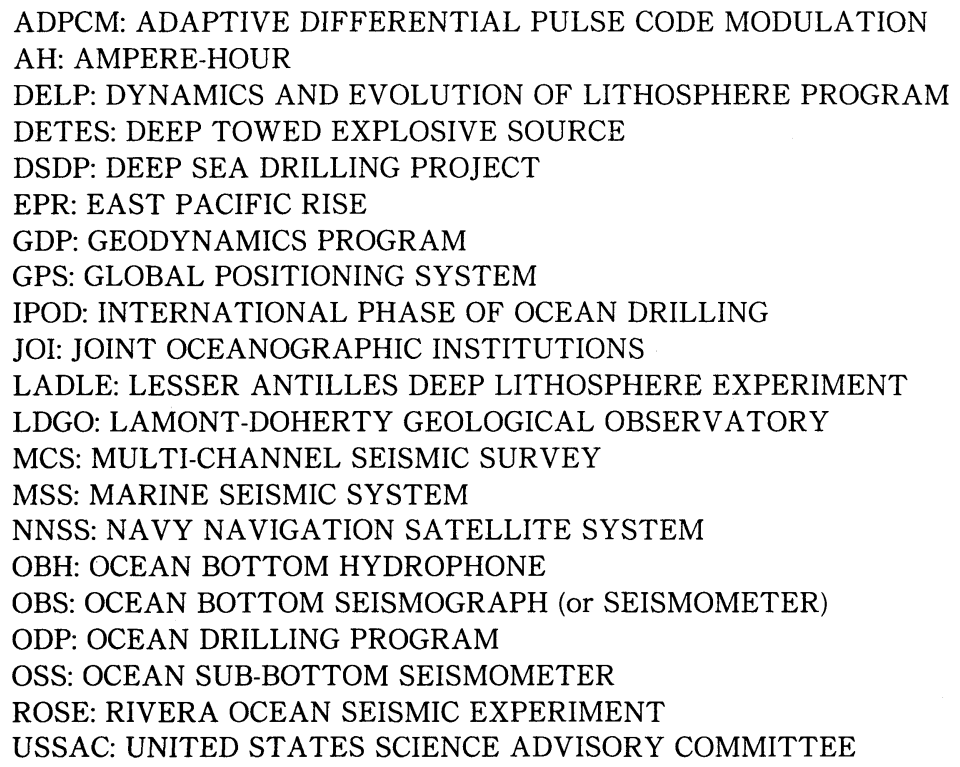

\section{文献}

Asada, T. and S. Shimamura, 1979, Long-range refraction experiments in deep ocean, Tectonophys., 56, 67-82.

Asada, T., H. Shimamura, T. Yamada, S. Asano, K. Kobayashi and Y. Tomoda, 1983, Explosion seismological experiments on long-range profiles in the northwestrn Pacific and the Marianas Sea, in T. W. C. Hilde and S. Uyeda (eds.), Geodynamics of the Western Pacific-Indonesian Region, Geodynamics Ser., 11, 105-120, AGU and GSA, U.S.A.

浅田 敏・島村英紀, 1974, 海底地震計と新らしい地球 物理学, 科学, 44, 278-285.

Butler, R., 1985, Anisotropic propagation of P- and S-waves in the western pacific lithosphere, Geophys. J. Roy. Astr. Soc., 81, 89-101.

Byrne, D. A., G. H. Sutton, J. G. Blackinton and F. K. Duennebier, 1983, Isolated sensor ocean bottom seismometer, Mar. Geophys. Res., 5, 437-449.

Byrne, D. A., D. Harris, F. K. Duennebier and R. CEssaro, 1987, The ocean sub-bottom seismometer system installed in Deep Sea Drilling Project Hole 581C Leg 88: a technical review, in Duennebier, F. K., R. Stephen, J. F. Gettrust et al., 1987, Init. Repts. DSDP, 88, 65-88, Washington (U.S. Govt. Printing Office).

Creager, K. C. and L. M. Dorman, 1982, Location of instruments on the seafloor by joint adjustment of instrument and ship positions, J. Geophys. Res., 87, 8379-8388.

Dorman, L. M., J. A. Hildebrand, P. T. C. Hammer, A. W. Sauter and A.E. Schreiner, 1986, Seismic study of a seamount interior, EOS, 67, 1083.

Dorman, L. M., A. E. Schreiner, A. W. Sauter, L. D. Bibee, J. A. Hildebrand and F. N. Spiess, 1988, On the relevance of seafloor array experiments to borehole seismic systems, in eds., Purdy, G. M. and A. M. Dziewonski, Proceedings of a workshop on broad-band downhole seismometers in the deep ocean, JOI/USSAC, Woods Hole, 143-157.

Duennebier, F.K., 1987, The 26 May 1983 Japan Earthquake recorded by OSS IV, in Duennebier, F. K., R. Stephen, J. F. Gettrust et al., 1987, Init Repts. DSDP, 88, 155-160, Washington (U.S. Govt. Printing Office).

Duennebier, F. K., P. N. Anderson and G. J. Fryer, 1987, Azimuth determination of and from horizontal ocean bottom seimic sensors, J. Geophys. Res., 92, 3567-3572.

Ewing, J. and M. Ewing, 1961, A telemetering oceanbottom seismograph, J. Geophys. Res., 66, 38633878.

Ewing, J. I. and R. P. Meyer, 1982, Rivera Ocean Seismic Experiment (ROSE) overview, J. Geophys. Res., 87, 8345-8358.

Frohlich, C., S. Billington, E. R. Engdahl and A. Malahoff, 1982, Detection and location of earthquakes in the central Aleutian subduction zone using island and ocean bottom seismograph stations, J. Geophys. Res., 87, 6853-6864.

Fujinawa, Y., M. Kubota, T. Eguchi and M. Ukawa, 1987, A direct recording pop-up type ocean bottom seismograph: CDPOBS IIa, Rep. National Res. Ctr. for Disaster Prev., 39, 19-35.

Harding, A. J., J. A. Orcutt, M. E. Kappus, E. E. Vera, 
J. C. Mutter, P. Buhl, R. S. Detrick and T.M. BROCHER, 1989, Structure of young oceanic crust at $13^{\prime} \mathrm{N}$ on the East Pacific Rise from expanding spread profiles, J. Geophys. Res., 94, 12163-12196.

Harris, M. M., J. A. Ballard, C. C. Mulcahy, A. EndRESS, R. L. Walterstedt, E. L. Kiser and N. Gough, 1987, Marine seismic system experiment, in Menard, H. W., J. Natland, T. H. Jordan, J. A. Orcutt, et al., 1987, Init. Repts. DSDP, 91, 307-333, Washington (U.S. Govt. Printing Office).

Hirata, N., T. Kanazawa, K. Suyehiro, T. Iwasaki and H. Shimamura, 1989, Observations of microseismicity in the southern Kurile Trench area by arrays of ocean bottom seismometers, Geophys. J. Int., 98, 55-68.

INATANI, H. and I. Furuya, 1980, A microprocessor controlled time code generator for an OBS system, J. Phys. Earth, 28, 281-292.

Ingle, J., K. Suyehiro, M. Von Breymann and Shipboard Party, 1990, Proc., Init. Repts. (Pt. A), ODP, 128: College Station, TX (in print).

Iwasaki, T., N. Hirata, T. Kanazawa, J. Melles, K. Suyehiro, T. Urabe, L. Moller, J. Makris and H. Shimamura, 1990, Crustal and upper mantle structure in the Ryukyu Island Arc deduced from deep seismic sounding, Geophys. J. Int., 102, in print.

JАсов, A. W. B., 1975, Dispersed shots at optimum depth-an efficient seismic source for lithospheric studies, J. Geophys., 41, 63-70.

金沢敏彦, 1986, 7 成分記録・低消費電力の超音波切離 式海底地震計, 昭和 63 年秋季地震学会予稿集, C50, 240.

笠原順三・是沢定之・南雲昭三郎 - 大工原 保 - 原 智 美・安藤誠一, 1979, 自己浮上式海底地震計 (ERI 型 P-79), 地震研彙報, 54, 515-530.

笠原順三・南雲昭三郎・是沢定之 - 大工原 保 - 宮田秀 明, 1980 , 底層流による海底地震計周囲の渦の発生の 実験的観察, 地震研彙報, 55, 169-182.

Kasahara, J., S. Nagumo, S. Koresawa, Y. Nishi and H. Sugimoto, 1982, A linear trend of hypocenter distribution in the outer slope region of the Japan Trench revealed by OBS array-preliminary report, Bull. Earthq. Res. Inst, Univ. Tokyo, 57, 83104.

Kasahara, J., M. Takahashi, T. Matsubara and M. KomiY A, 1985, Mass storage digital ocean bottom seismometer and hydrophone (DOBSH) controlled by micro-processors using ADPCM voice synthesizing, Bull Earthq. Res. Inst., Univ. Tokyo, 60, 23-37.

Koelsch, D.E., W.E. Witzell, J.E. Broda, F. B. Wooding and G. M. Purdy, 1986, A deep towed explosive source for seismic experiments on the ocean floor, Mar. Geophys. Res., 8, 345-361.

気象研究所地震火山研究部, 1980 , 海底地震常時観測 ステムの開発, 気象研究所技術報告, $4,233 \mathrm{pp}$.

The Ladle Study Group, 1983, A lithosphere seismic refraction profile in the western North Atlantic Ocean, Geophys. J. Roy. Astr. Soc., 75, 23-69.

Langseth, M. G. and F. N. Speiss, 1987, Science opportunities created by wireline reentry of deepsea boreholes, JOI/USSAC, pp. 65, Scripps Inst. Oceanogr.

Legrand, J., A. Echardour, H. Floch, L. Floury, J. Gieskes, F. Harmegnies, G. Loaec, J. -P. Pozzi, Y. RAER and R. Stephen, 1989, Campagne FARE, wireline reentry of DSDP Hole $396 \mathrm{~B}$ using the NADIA system, EOS, 70, 729-730, 741.

LeRner-LAM, A. L., 1988, Seismological studies of the lithosphere, Lamont-Doherty Geol. Obs. Yearbook, 50-55.

McClain, J. S., J. A. Orcuit and M. Burnett, 1985, The East Pacific Rise in cross section: a seismic model, J. Geophys. Res., 90, 8627-8639.

Moore, R. D., L. M. Dorman, C. Y. Huang and D. L. Berliner, 1981, An ocean bottom microprocessor based seismometer, Mar. Geophys. Res., 4, 457-477.

Nagumo, S. and J. Kasahara, 1976, Ocean-bottom seismograph study of the western margin of the Pacific, in eds., Sutton, G. H. et al., The geophysics of the Pacific Ocean basin and its margin, Geophys. Monogr. 19, 155-169, Am. Geophys. U., Washington.

Nagumo, S., T. Ouchi, J. Kasahara, S. Koresawa, Y. Tomoda, K. Kobayashi, A. S. Furumoto, M. E. Odegard and G. H. Sutton, 1981, Sub-Moho seismic profile in the Mariana basin- ocean bottom seismograph long-range explosion experiment, Earth Planet. Sci. Lett., 53, 93-102.

南雲昭三郎, 1980, 海底地震計ヨーロッパ・アジア国際 比較試験に参加して, 地球, 2, 663-672.

南雲昭三郎・笠原順三・是沢定之, 1982 , 自己浮上式海 底地震計の位置精度, 地震研彙報, 57, 1119-123.

南雲昭三郎・笠原順三・是沢定之・村上英幸, 1982 , 音 響切り離し方式海底地震計 (ERI-AR81 型), 地震研 彙報, 57, 1125-132.

Nakamura, Y., P. L. Donoho, P. H. Poper and P. M. McPherson, 1987, Large-offset seismic surveying using ocean-bottom seismographs and air guns: instrumentation and field technique, Geophys., 52 , 1601-1611.

Nishizaw A, A. and K. Suyehiro, 1986, Crustal structure across the Kurile Trench off southeastern Hokkaido by airgun-OBS profiling, Geophys. J. Roy. Astr. Soc., 86, 371-397.

Prothero, W. A., 1984, Ocean bottom seismometer technology, EOS, 65, 113-116.

Purdy, G. M., 1987, New observations of the shallow seismic structure of young oceanic crust, J. Geophys. Res., 92, 9351-9362.

Purdy, G. M. and A. Dziewonski, 1988, Proceedings of a workshop on broad-band downhole seismometers in the deep ocean, JOI/USSAC, $331 \mathrm{pp}$.

島村英紀・浅田 敏, 1978, 海底の地震学・その課題之 
展望, 号外海洋科学, 1, 204-218.

島村英紀, 1981, 海底地震計の列国事情, 自然, 4 月号, 59-68.

島村英紀, 1988, 地球の腹と胸の内, 情報センター出版 局, 262 pp.

Shimamura, H., T. Asada, K. Suyehiro, T. Yamada and $H$. InAtani, 1983, Longshot experiments to study velocity anisotropy in the oceanic lithosphere of the northwestern Pacific, Phys. Earth Planet. Inter., 31, 348-362.

Shimamura, H., 1984, Anisotropy in the oceanic lithosphere of the Northwestern Pacific Basin, Geophys. J. Roy. Astr. Soc., 76, 253-260.

Shimamura, H. and T. Kanazawa, 1988, Ocean bottom tiltmeter with acoustic data retrieval system implanted by a submersible, Mar. Geophys. Res., 9, 237-254.

Stephen, R. A., F. K. Duennebier, D. R. Bellows and A. InDERBITZEN, 1987, Wireline reentry test on DSDP Leg 88, in Duennebier, F. K., R. Stephen, J. F. Gettrust et. al., 1987, Init Repts. DSDP, 88, 59-64, Washington (U.S. Govt. Printing Office).

Stoffa, P. L. and P. Buhl, 1979, Two-ship multichannel seismic experiment for deep crustal studies: expanded spread and constant offset profiles, J. Geophys. Res., 84, 7645-7660.

Sutton, G. H., W. G. McDonald, D. D. Prentiss and S. N. Thanos, 1965, Ocean-bottom seismic observatories, Proc. of the IEEE, 53, 1909-1921.

Sutton, G. H., F. K. Duennebier, B. Iwatake, J. TutHILL, B. Lewis and J. EwING, 1981, An overview and general results of the Lopez Island OBS experiment, Mar. Geophys. Res., 5, 3-34.

Sutton, G. H. and F. K. Duennebier, 1987, Optimum design of ocean bottom seismometers, Mar. Geophys. Res., 9, 47-65.

Suyehiro, K., T. Kanazawa, A. Nishizawa and $H$. Shimamura, 1985, Crustal structure beneath the inner trench slope of the Japan Trench, Tectonophys., 112, 155-191.

末広 潔, 1987, 西太平洋海盆の地震波速度構造, 海洋 科学, 19, 412-417.

Suehiro, K., T. Kanazawa and H. Shimamura, 1988, Lower lithosphere structure of the subducting

plate, Seismol. Res. Lett., 59, 52.

Swift, S. A. and R. A. Stephen, 1989, Lateral heterogeneity in the seismic structure of upper oceanic crust, western north Atlantic, J. Geophys. Res., 94, 9303-9322.

友田好文・鈴木弘道・土屋 淳, 1985 , 地球観測ハンド ブック，東京大学出版会，東京， $830 \mathrm{pp}$.

Trehu, A. M. and S. C. Solomon, 1983, Earthquakes in the Orozco transform zone: seismicity, source mechanisms, and tectonics, J. Geophys. Res., 88, 8203-8225.

Trehu, A. M., 1985, Coupling of ocean bottom seismometers to sediment: results of tests with the U.S. Geological Survey ocean bottom seismometer, Bull. Seism. Soc. Am., 75, 271-289.

筒井智樹・安藤雅孝・金嶋 聡・大滝壽樹, 1989 , デジ タル海底地震計の開発と海底地震観測, 海洋科学技術 センター試験研究報告, 293-302.

Turgut, A., T. Yamamoto, C. Авbott, M. Badiey, M. Trevorrow and D. Goodman, 1987, High resolution bottom shear modulus profiler: a shallow water real-time OBS array, GAL Report \#1005, Univ. of Miami, $48 \mathrm{pp}$.

卜部 卓・平田 直, 1984, ミニコンピュータによる, 長時間海底地震記録テープの自動再生処理システム, 地震 $2,37,633-645$.

Urabe, T., K. Suyehiro, T. Iwasaki, N. Hirata T. Kanazawa, A. Nishizawa and H. Shimamura, 1985, Aftershock distribution of the 1983 Japan Sea earthquake as determined from helicopterdispatched OBS observation, J. Phys. Earth, 33, 133-147.

Walker, D. A. and C. McCreery, 1985, Significant unreported earthquakes in "aseismic" regions of the western Pacific, Geophys. Res. Lett., 12, 433436.

Whitmarsh, R. B. and R. C. Lilwall, 1983, Oceanbottom seismographs, In eds. Bott et al., Structure and Development of the Greenland-Scotland Ridge, 257-286, Plenum Publishing Corp., U.S.A.

山田敏彦, 1980, 海底地震計による精密観測に基づくサ ブダクション領域の震源立体分布と地殼構造, 東京大 学博士論文. 